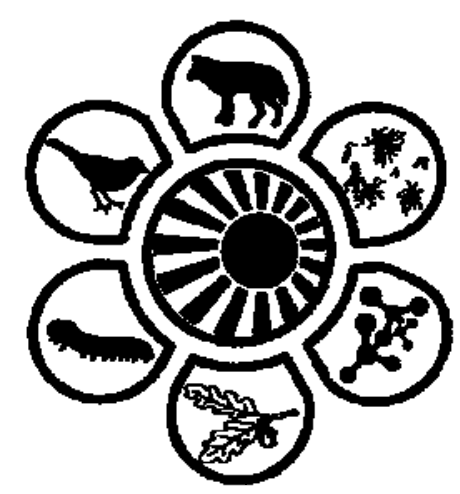

Вісник Дніпропетровського університету. Біологія, екологія.

Vìsnik Dnìpropetrovs'kogo unìversitetu. Seriâ Bìologiâ, ekologiâ

Visnyk of Dnipropetrovsk University. Biology, ecology.

Vìsn. Dnìpropetr. Unìv. Ser. Bìol. Ekol. 2016. 24(1), 188-192.

doi: $10.15421 / 011623$

ISSN 2310-0842 print

ISSN 2312-301X online

www.ecology.dp.ua

UDK 581.13:577.15/581.45

\title{
The impact of pollutants on the antioxidant protection of species of the genus Tilia at different developmental stages
}

\author{
A.A. Alexeyeva ${ }^{1}$, Y.V. Lykholat ${ }^{1}$, N.O. Khromykh ${ }^{1}$, I.M. Kovalenko ${ }^{2}$, E.S. Boroday ${ }^{1}$ \\ ${ }^{1}$ Oles Honchar Dnipropetrovsk National University, Dnipropetrovsk, Ukraine \\ ${ }^{2}$ Sumy National Agricultural University, Sumy, Ukraine
}

\begin{abstract}
The influence of transport fumes and industrial waste on the activity of catalase, benzidine-peroxidase and guaiacol-peroxidase was studied in the dormant buds, leaves and seeds of the following species of the genus Tilia: T. platyphyllos Scop., T. europaea L., T. amurensis Rupr. and T. begoniifolia Stev. We tested the hypothesis that the action of pollutants changes the state of antioxidant protection at different stages of tree development in contaminated phytocenoses. An increase in catalase activity was observed in leaves of all linden species, and the action of transport fumes caused excess over control level by 118,118, 196, and 61\% respectively for T. platyphyllos, T. europaea, T. amurensis and T. begoniifolia. The action of industrial waste was accompanied by a slight decrease in catalase activity in $T$. europaea leaves, and increase in activity in leaves of T. amurensis and T. begoniifolia (143\% and $115 \%)$. Benzidine-peroxidase activity increased due to the influence of transport fumes on leaves of T. amurensis and T. begoniifolia (103\% and 44\%), but decreased due to the effect of industrial waste on leaves of T. europaea, T. amurensis and T. begoniifolia ( $46 \%, 30 \%$, and $44 \%$ respectively), and was suppressed in the seeds of T. europaea, T. amurensis and T. begoniifolia both under the influence of transport (42\%, 47\% and $33 \%$ below control) and industrial emissions (19\%, 19\% and 45\%), and was reduced in buds of T. platyphyllos, T. europaea and T. amurensis due to the effect of transport fumes (21\%, $9 \%$ and $20 \%$ respectively). Guaiacol-peroxidase activity decreased due to the influence of transport fumes in buds of T. platyphyllos, T. europaea and T. amurensis (41\%, 14\% and 47\% below control), while it increased in the seeds of T. platyphyllos and T. amurensis (104\% and 83\%), as well as in leaves of T. amurensis and T. begoniifolia both due to the effect of transport (129\% and $144 \%)$ and of industrial emissions (respectively, 34\% and 40\% above control). The substantial restructuring of the antioxidant system components in leaves, dormant buds and seeds confirms the hypothesis that metabolic processes in Tilia trees adapt throughout all stages of their development in response to the polluted conditions in urban phytocenoses.
\end{abstract}

Key words: linden tree; bud; leaf; seed; contamination; catalase; benzidine-peroxidase; guaiacol-peroxidase

\section{Вплив полютантів на антиоксидантний захист видів роду Tilia на різних стадіях розвитку}

\author{
А.А. Алексєєва ${ }^{1}$ Ю.В. Лихолат ${ }^{1}$, Н.О. Хромих ${ }^{1}$ І І.М. Коваленко ${ }^{2}$, С.С. Бородай ${ }^{1}$ \\ ${ }^{1}$ Дніпропетровський національний університет імені Олеся Гончара, Дніпропетровськ, Украӥна \\ ${ }^{2}$ Сумський національний аграрний університет, Суми, Украӥна
}

\begin{abstract}
Досліджено вплив транспортних вихлопів і промислових викидів на активність каталази, бензидин-пероксидази та гваяколпероксидази у бруньках, листках і насінні Tilia platyphyllos Scop., T. europaea L., T. amurensis Rupr. і T. begoniifolia Stev. Перевірено гіпотезу про те, що вплив полютантів змінює стан антиоксидантного захисту на різних стадіях розвитку дерев у забруднених фітоценозах. Зростання активності каталази спостерігали у листках усіх видів лип. Вплив транспортних вихлопів спричинив збільшення контрольного рівня для T. platyphyllos на 118\%, для T. europaea - на 118\%, для T. amurensis - на 196\% і для T. begoniifolia - на $61 \%$. Вплив промислових викидів супроводжувався незначним зниженням активності каталази у листках $T$. europaеa та зростанням активності у листках T. amurensis i T. begoniifolia (на 143\% і 115\% відповідно). Активність бензидин-пероксидази зростала за
\end{abstract}

Дніпропетровський національний університет імені Олеся Гончара, пр. Гагаріна, 72, Дніпропетровськ, 49010, Україна Oles Honchar Dnipropetrovsk National University, Gagarin Ave., 72, Dnipropetrovsk, 49010, Ukraine Tel.:+38-050-487-87-17.E-mail: khromykh58@rambler.ru

Сумський національний аграрний університет, вул. Герасима Кондратьєва, 160, Суми, 40021, Украина Sumy National Agricultural University, 160, Gerasym Kondratjev Str., 160, Sumy, 40021, Ukraine 
дії транспортних вихлопів у листках T. amurensis і T. begoniifolia (відповідно, на 103\% і 44\%), проте знижувалась за дії промислових викидів у листках T. europaea, T. amurensis і T. begoniifolia (на 46\%, 30\% і 44\% відносно контролю відповідно), а також була пригнічена у насінні T. europaea, T. amurensis і T. begoniifolia як за дії транспортних (відповідно, на 42\%, 47\% і 33\% від контролю), так і промислових емісій (на 19\%, 19\% і 45\% від контролю, відповідно), та знижена у бруньках T. platyphyllos, T. europaea та T. amurensis за дії транспортних вихлопів (на 21\%, 9\% і 20\% від контролю, відповідно). Активність гваякол-пероксидази за впливу транспортних вихлопів знижувалась у бруньках T. platyphyllos, T. europaea i T. amurensis (відповідно, на 41\%, 14\% і 47\% відносно контролю), але збільшувалась у насінні T. platyphyllos і T. amurensis (на 104\% і 83\%, відповідно), а також зростала у листках T. amurensis i T. begoniifolia як за дії транспортних (відповідно, на 129\% і 144\%), так і промислових емісій (відповідно, на 34\% і 40\% відносно контролю). Суттєві перебудови компонентів антиоксидантної системи у листках, бруньках і насінні підтвердили припущення, що адаптація дерев роду Tilia до умов забруднених міських фітоценозів потребує змін метаболічних процесів упродовж усіх стадій розвитку.

Ключові слова: липа; бруньки; листки; насіння; забруднення; каталаза; бензидин-пероксидаза; гваякол-пероксидаза

\section{Introduction}

Along with the unfavorable environmental conditions the action of pollutants is an additional factor complicating tree development in the urban phytocenoses of the Steppe zone. Anthropogenic impact on plant communities is an urgent problem for Dnipropetrovsk, where the volume of industrial emissions accounts for $17 \%$ of Ukraine's total emissions (Pakhomov and Brygadyrenko, 2005), currently reaching more than 1 million tons per year (Striletz, 2015; Tsvetkova et al., 2016). The adverse effect of pollutants can manifest itself in various functional changes in trees such as a decrease in the photosynthetic pigment content of leaves (Deniz and Duzenli, 2007), or failure of the physiological and biochemical mechanisms regulating vital functions (Ramel et al., 2012). As Gill and Tuteja (2010) have found, the activation of plant protective mechanisms belonging to different levels of plant organization, has a crucial role in the formation of resistance to the action of abiotic stressors. Moreover, Chirkova (2004) emphasizes the necessity of simultaneous realization of detoxification of xenobiotics and the recovery processes of cellular homeostasis in plants. Therefore, understanding the metabolic adaptation of plants to polluted environments involves the study of the cellular defense mechanisms, including activation of antioxidant enzymes.

Many authors note the obvious importance of trees in urban phytocenoses as an indicator of local contamination (Madejon et al., 2004; Kardel et al., 2012), as well as an effective factor that can ameliorate a polluted environment (Matyssek et al., 2012). Trees are able to improve the microclimate and overall ecological conditions of industrial cities by regulating carbon dioxide content in the air, as well as by air oxygen saturation (Roy et al., 2012). In addition, plant organs accumulate trace elements (Madejon et al., 2004) together with heavy metals and the oxides of sulfur and nitrogen (Fisher et al., 2002). The highest ability of trees to retain dust is inherent in species with a large leaf area; for example, one Tilia cordata tree holds about $5.4 \mathrm{~g} / \mathrm{m}^{3}$ of dust transmitted from the air, as Divan et al. (2009) have shown. According to Sheykholeslami et al. (2008), the leaf surface of Tilia platyphyllos can absorb more than $9 \mathrm{mg} / \mathrm{m}^{2}$ per hour of sulfur oxide. In general, all species of the genus Tilia are able to accumulate a considerable amount of pollutants, including trace elements (Anicic et al., 2011), as well as compounds of lead, cadmium, nickel, chromium, and cobalt (Tomaševic et al., 2004). It was found that the impact of pollutants on the different species of the genus Tilia can affect the anatomical features of leaves (Koshiba, 2008). However, very little attention has been paid to the study of metabolic mechanisms determining adaptation of linden species to contaminated environments. The objectives of our work were to identify the patterns of antioxidant system response of Tilia species to the chronic effects of pollutants, and to determine whether the influence of pollutants is evident at different stages of development of the trees in urban phytocenoses.

\section{Material and methods}

The test objects were the dormant buds, leaves and seeds of T. platyphyllos Scop., T. europaea L., T. amurensis Rupr. and T. begoniifolia Stev. The samples of the plant organs were collected in the Dnipropetrovsk Botanical Garden (plot 1, control; 48 $\left.26^{\prime} 09.6^{\prime \prime} \mathrm{N}, 35^{\circ} 02^{\prime} 31.2^{\prime \prime} \mathrm{E}\right)$ and in the urban phytocenoses: polluted with transport fumes containing sulfur dioxide and carbon oxides as well as volatile organic compounds (plot 2, 48 $28^{\prime} 12.4^{\prime \prime} \mathrm{N}, 35^{\circ} 02^{\prime} 20.3^{\prime \prime} \mathrm{E}$, and plot 3, $48^{\circ} 28^{\prime} 23.6^{\prime \prime} \mathrm{N}, 35^{\circ} 00^{\prime} 27.6^{\prime \prime} \mathrm{E}$ ), and industrial waste containing much larger quantities of carbon, nitrogen, and sulfur oxides together with the solid contaminants (plot 4, 48 $28^{\prime} 40.4^{\prime \prime} \mathrm{N}$, $34^{\circ} 59^{\prime} 03.5^{\prime \prime} \mathrm{E}$, and plot 5, 48 28'26.7" N, 3457'29.1" E). The dormant buds were taken in March 2015, the leaves in August from 5-7 evenly-aged trees of each Tilia species, and the samples were stored in a frozen state; the seeds were collected in October 2015 and air dried to constant weight.

The activity of antioxidant enzymes was determined by the spectrophotometric method in the supernatants obtained by centrifugation $\left(12,000 \mathrm{~g}\right.$ for $20 \mathrm{~min}$ and $4{ }^{\circ} \mathrm{C}$ ) of crude extracts (100 mg of tissue homogenized with $2.5 \mathrm{ml}$ of Tris- $\mathrm{HCl}$ buffer contained $0.1 \%$ polyvinylpyrrolidone, $\mathrm{pH}$ 7.0). Enzyme activity measured in the buds and leaves was expressed in the respective units per $g$ fresh weight, while activity in the seeds was expressed in the units per g dry weight.

Activity of catalase (CAT, EC 1.11.1.6) was measured according to Goth (1991) at $410 \mathrm{~nm}$ in a reactive mixture containing $1.2 \mathrm{ml}$ of $0.1 \% \mathrm{H}_{2} \mathrm{O}_{2}, 1 \mathrm{ml}$ of $4 \%$ ammonium molibdate, and $0.2 \mathrm{ml}$ of sample. Enzyme activity was calculated by using a calibration graph and expressed in $\mathrm{mM}$ $\mathrm{H}_{2} \mathrm{O}_{2} \min ^{-1} \mathrm{~g}^{-1}$. Determination of peroxidase (POD, EC 1.11.1.7) activity was based on the method of Gregory (1966) with benzidine as a protons donor, and on the method of Ranieri et al. (1997) with guaiacol. Activity of benzidineperoxidase (BPOD) was measured at $490 \mathrm{~nm}$ in a reactive mixture $(0.8 \mathrm{ml}$ of acetate buffer, $1 \mathrm{ml}$ of benzidine and $0.2 \mathrm{ml}$ sample) after adding $1 \% \mathrm{H}_{2} \mathrm{O}_{2}$, and the result was expressed in optical units $\mathrm{min}^{-1} \mathrm{~g}^{-1}$. Guaiacol-peroxidase (GPOD) activity was determined by the change within $1 \mathrm{~min}$ of the reaction mixture $(0.75 \mathrm{ml}$ of acetate buffer, $0.25 \mathrm{ml}$ of 
guaiacol, $0.25 \mathrm{ml}$ of $\mathrm{H}_{2} \mathrm{O}_{2}$, and $0.25 \mathrm{ml}$ sample) absorbance at $470 \mathrm{~nm}$, and expressed in $\mathrm{mM}$ guaiacol $\mathrm{min}^{-1} \mathrm{~g}^{-1}$.

All determinations were performed in three replicates. Data represent mean values and standard deviations ( \pm SD). Significance of differences was estimated using Fisher's test $(\mathrm{P}<0.05)$, and asterisk $(*)$ indicates significant difference from control.

\section{Results and discussion}

In our study, changes of catalase activity were revealed in the organs of all Tilia species from polluted phytocenoses in comparison with the control level (Table 1). The most notable increase in CAT activity was observed in the leaves of lindens, and influence of transport fumes caused excess over control level by $118 \%, 118 \%, 196 \%$, and $61 \%$ respectively for T. platyphyllos, T. europaea, T. amurensis and T. begoniifolia ( $\mathrm{P}<0.05$ for each case). The effect of industrial waste was accompanied by insignificant decrease in catalase activity in T. europaea leaves, but activity increased in leaves of T. amurensis and T. begoniifolia (143\% and 115\% above control respectively, $\mathrm{P}<0.05$ ).

Table 1

Effect of pollutants on catalase activity $\left(\mathrm{mM} \mathrm{H}_{2} \mathrm{O}_{2} \mathrm{~min}^{-1} \mathrm{~g}^{-1}\right)$ of linden organs (Mean $\pm \mathrm{SD}, \mathrm{n}=\mathbf{1 2})$

\begin{tabular}{|c|c|l|l|l|}
\hline Species & Plots & \multicolumn{1}{c|}{ Buds } & \multicolumn{1}{c|}{ Leaves } & \multicolumn{1}{c|}{ Seeds } \\
\hline \multirow{2}{*}{ T. platyphyllos } & 1 & $230.7 \pm 3.46$ & $22.4 \pm 3.70$ & $134.4 \pm 3.00$ \\
\cline { 2 - 5 } & 3 & $211.5 \pm 2.37 *$ & $48.9 \pm 6.36^{*}$ & $231.4 \pm 2.83^{*}$ \\
\hline \multirow{3}{*}{ T. europaea } & 1 & $282.3 \pm 3.12$ & $35.7 \pm 3.36$ & $236.2 \pm 4.56$ \\
\cline { 2 - 5 } & 3 & $291.0 \pm 2.60$ & $78.0 \pm 4.81 *$ & $417.7 \pm 3.12^{*}$ \\
\cline { 2 - 5 } T. amurensis & 4 & $299.7 \pm 3.22$ & $34.7 \pm 1.99$ & $204.8 \pm 3.70^{*}$ \\
\hline \multirow{3}{*}{ T. begoniifolia } & 2 & $231.6 \pm 1.44$ & $30.3 \pm 1.47$ & $318.6 \pm 1.16$ \\
\cline { 2 - 5 } & 2 & $239.4 \pm 2.74$ & $89.9 \pm 3.27 *$ & $322.4 \pm 5.11$ \\
\cline { 2 - 5 } & 2 & $214.3 \pm 3.07 *$ & $73.7 \pm 2.24 *$ & $334.5 \pm 3.22^{*}$ \\
\cline { 2 - 5 } & 2 & $229.8 \pm 3.25$ & $47.3 \pm 2.61 *$ & $237.3 \pm 3.18^{*}$ \\
\hline
\end{tabular}

Significant differences in catalase activity between samples from control and polluted plots are indicated by $*-\mathrm{P}<0.05$.

Changes of catalase activity in the dormant buds were not substantial: increase in activity was observed in the buds of T. europaea under the influence of both transport and industrial emissions, while in the buds of T. amurensis and $T$. begoniifolia - only under the influence of transport fumes. Enzyme activity was suppressed by the influence of transport fumes in the buds of $T$. platyphyllos $(8 \%$ below control, $\mathrm{P}<$ 0.05 ), and by the influence of industrial waste in the buds of T. amurensis $(7 \%$ below control, $\mathrm{P}<0.05)$. Activity of catalase increased due to the influence of transport emissions in the seeds of T. platyphyllos and T. europaea ( $72 \%$ and $77 \%$ above control, $\mathrm{P}<0.05)$, while it decreased $(13 \%$ below control, $\mathrm{P}<0.05$ ) in $T$. europaea seeds due to the effect of industrial waste. Enzyme activity increased insignificantly in seeds of T. amurensis, but decreased drastically in seeds of $T$. begoniifolia under the influence of transport and industrial emissions ( $28 \%$ and $46 \%$ respectively, $\mathrm{P}<0.05$ ). In our study, notable benzidine-peroxidase activity was observed to increase basically only in the leaves of each linden species, while it was less expressed in the dormant buds (Table 2).
Activity of benzidine-peroxidase increased due to the effect of transport fumes in leaves of $T$. platyphyllos (insignificantly), and leaves of $T$. amurensis and T. begoniifolia (respectively, 103\% and 44\% above control, $\mathrm{P}<0.05$ ), but decreased in $T$. europaea leaves. The influence of industrial emissions caused a sharp decline in enzyme activity in leaves of T. europaea, T. amurensis and T. begoniifolia (respectively, $46 \%, 30 \%$ and $44 \%$ below control, $\mathrm{P}<0.05$ ).

Benzidine-peroxidase activity was reduced in buds of T. platyphyllos, T. europaea and T. amurensis both due to the effect of transport fumes (respectively, 21\%, 9\% and 20\% below control, $\mathrm{P}<0.05$ ) and industrial waste (insignificantly). By contrast, benzidine-peroxidase was activated in T. begoniifolia buds due to the effect of both transport and industrial emissions (respectively, $11 \%$ and $30 \%$ above control, $\mathrm{P}<0.05$ for plot 4). Benzidine-peroxidase activity of seeds was suppressed for T. europaea, T. amurensis and T. begoniifolia both under the influence of transport (respectively, 42\%, 47\% and 33\% below control, $\mathrm{P}<0.05$ ) and industrial emissions (respectively, 19\%, 19\% and 45\%, $\mathrm{P}<0.05$ ); decrease in enzyme activity in $T$. platyphyllos seeds was insignificant. In our study, activity of guaiacol-peroxidase was reduced in leaves of $T$. platyphyllos $(37 \%, \mathrm{P}<0.05)$ and $T$. europaea ( $24 \%$ and $44 \%$, respectively due to the influence of transport and industrial emissions, $\mathrm{P}<0.05$ ), while it increased in leaves of other Tilia species (Table 3).

Effect of pollutants on benzidine-peroxidase activity (optical units $\mathrm{min}^{-1} \mathrm{~g}^{-1}$ ) of linden organs (Mean $\pm \mathrm{SD}, \mathrm{n}=12$ )

\begin{tabular}{|c|c|c|c|c|}
\hline Species & Plots & Buds & Leaves & Seeds \\
\hline \multirow{2}{*}{ T. platyphyllos } & 1 & $102.4 \pm 3.20$ & $3.9 \pm 0.95$ & $52.7 \pm 3.36$ \\
\cline { 2 - 5 } & 3 & $81.2 \pm 1.99 *$ & $4.1 \pm 1.87$ & $48.1 \pm 3.14$ \\
\hline \multirow{3}{*}{ T. europaea } & 1 & $32.0 \pm 3.44$ & $16.0 \pm 2.58$ & $72.9 \pm 5.53$ \\
\cline { 2 - 5 } & 3 & $29.2 \pm 3.33 *$ & $14.0 \pm 1.67$ & $42.4 \pm 1.87 *$ \\
\cline { 2 - 5 } & 4 & $30.4 \pm 2.89$ & $8.4 \pm 1.17 *$ & $58.8 \pm 2.29 *$ \\
\hline \multirow{3}{*}{ T. amurensis } & 1 & $44.8 \pm 3.99$ & $8.1 \pm 1.13$ & $57.4 \pm 6.07$ \\
\cline { 2 - 5 } & 2 & $34.6 \pm 1.78^{*}$ & $16.5 \pm 2.20 *$ & $30.2 \pm 3.79 *$ \\
\cline { 2 - 5 } & 5 & $38.8 \pm 3.22$ & $5.7 \pm 0.94 *$ & $46.4 \pm 4.86^{*}$ \\
\hline \multirow{3}{*}{ T. begoniifolia } & 1 & $14.8 \pm 1.56$ & $33.2 \pm 1.52$ & $112.5 \pm 2.48$ \\
\cline { 2 - 5 } & 2 & $16.4 \pm 1.85$ & $47.7 \pm 1.99 *$ & $86.8 \pm 2.14 *$ \\
\cline { 2 - 5 } & 4 & $19.2 \pm 2.20 *$ & $18.4 \pm 1.80 *$ & $61.9 \pm 1.42 *$ \\
\hline
\end{tabular}

Significant differences in benzidine-peroxidase activity between samples from control and polluted plots are indicated by $*-\mathrm{P}<0.05$.

Effect of pollutants on guaiacol-peroxidase activity $\left(\mathrm{mM}\right.$ guaiacol $\left.\mathrm{min}^{-1} \mathrm{~g}^{-1}\right)$ of linden organs (Mean $\pm \mathrm{SD}, \mathrm{n}=12$ )

\begin{tabular}{|c|c|c|l|c|}
\hline Species & Plots & Buds & Leaves & Seeds \\
\hline \multirow{2}{*}{ T. platyphyllos } & 1 & $9.1 \pm 1.01$ & $6.0 \pm 1.01$ & $14.3 \pm 1.59$ \\
\cline { 2 - 5 } & 3 & $5.4 \pm 0.86^{*}$ & $3.8 \pm 0.87^{*}$ & $29.1 \pm 6.22^{*}$ \\
\hline \multirow{3}{*}{ T. europaea } & 1 & $6.6 \pm 0.65$ & $5.8 \pm 0.72$ & $7.3 \pm 0.92$ \\
\cline { 2 - 5 } & 3 & $5.7 \pm 0.50$ & $4.4 \pm 1.31$ & $4.0 \pm 0.14^{*}$ \\
\cline { 2 - 5 } & 4 & $4.8 \pm 0.57 *$ & $3.3 \pm 1.12^{*}$ & $6.1 \pm 0.87^{*}$ \\
\hline \multirow{3}{*}{ T. amurensis } & 1 & $15.3 \pm 1.82$ & $4.3 \pm 0.96$ & $3.5 \pm 0.70$ \\
\cline { 2 - 5 } & 2 & $8.1 \pm 0.88^{*}$ & $9.9 \pm 1.69 *$ & $6.4 \pm 1.33^{*}$ \\
\cline { 2 - 5 } & 5 & $7.5 \pm 0.89^{*}$ & $5.4 \pm 1.00$ & $9.8 \pm 1.62^{*}$ \\
\hline \multirow{3}{*}{ T. begoniifolia } & 1 & $6.9 \pm 0.93$ & $3.8 \pm 0.72$ & $10.8 \pm 2.26$ \\
\cline { 2 - 5 } & 2 & $9.6 \pm 1.37 *$ & $9.3 \pm 2.42^{*}$ & $9.0 \pm 2.17^{*}$ \\
\cline { 2 - 5 } & 4 & $8.4 \pm 1.13^{*}$ & $5.4 \pm 0.51^{*}$ & $11.1 \pm 2.64$ \\
\hline
\end{tabular}

Significant differences in guaiacol-peroxidase activity between samples from control and polluted plots are indicated by * $-\mathrm{P}<0.05$. 
Higher enzyme activation was observed in leaves of T. amurensis and T. begoniifolia under the influence of both transport fumes $(29 \%$ and $44 \%$ respectively, $\mathrm{P}<0.05)$ and industrial waste (respectively, $24 \%$ and $40 \%, \mathrm{P}<0.05$ ). The activity of guaiacol-peroxidase decreased in the buds of T. platyphyllos, T. europaea and T. amurensis under the influence of both transport fumes (respectively, 41\%, 14\% and $47 \%$ below control, $\mathrm{P}<0.05)$ and industrial waste $(27 \%$ and $51 \%$, respectively for the second and third species, $\mathrm{P}<$ $0.05)$. In contrast, increase in enzyme activity was observed in T. begoniifolia buds due to the influence of transport and industrial emissions as well (respectively, 39\% and 22\% above control, $\mathrm{P}<0.05)$.

Increase in guaiacol-peroxidase activity of seeds was revealed for $T$. platyphyllos due to the influence of transport fumes $(104 \%$ above control, $\mathrm{P}<0.05)$ and for $T$. amurensis due to the influence of both transport and industrial emissions (respectively $83 \%$ and $180 \%$ above control, $\mathrm{P}<0.05$ ). At the same time, enzyme activity was reduced under the influence of transport and industrial emissions in seeds of T. europaea ( $44 \%$ and $16 \%$ respectively, $\mathrm{P}<0.05$ ), as well as in $T$. begoniifolia seeds due to the influence of transport fumes $(17 \%$ below control, $\mathrm{P}<0.05)$.

Since Halliwell (2006) has shown that catalase and peroxidase functioning provides control of hydrogen peroxide, which can cause oxidative stress in the case of excessive accumulation, it is therefore apparent that changes of enzyme activity in the dormant buds, leaves and seeds from polluted plots suggest substantial shifts in the antioxidant processes. Differences of activation of antioxidant enzymes in the organs of linden species are consistent with the data obtained by Hammond-Kosack and Jones (1996) on the dependence of cells $\mathrm{H}_{2} \mathrm{O}_{2}$ level on duration and type of stress. Taking into account the opinion of Polovnikova (2008) that the reduction of catalase activity is a diagnostic feature of plant sensitivity to anthropogenic factors, we concluded that catalase plays a decisive role in the resistance of each Tilia species to polluted environments. In addition, it should be noted that there is a steady high level of catalase activity in the buds of all Tilia species as well as catalase activation in seeds of all species except $T$. begoniifolia. The results obtained correlate with the data of Khromykh et al. (2014) on adaptive direction of a significant increase in catalase activity in leaves of Acer negundo influenced by transport and industrial emissions during the growing season.

Referring to the opinion of Ranieri et al. (2001) about the important role of peroxidase in plant metabolism, the divergent changes of peroxidase activity in the buds, leaves, and seeds indicated a transformation of various physiological processes of Tilia species from the plots contaminated by transport and industrial emissions. According to our results, the greatest activation of guaiacol-peroxidase was observed in leaves of $T$. amurensis and T. begoniifolia, as well as in seeds of T. platyphyllos and T. amurensis; such trends can be related to the amplification of enzyme role in the metabolism of phenols and sugars, as was found by Allison and Schultz (2004), and Maksimović et al. (2008) for various plant species. At the same time, guaiacol-peroxidase activity was reduced drastically in the buds of Tilia species, except $T$. begoniifolia. Activity of benzidine-peroxidase increased in leaves of T. platyphyllos, T. amurensis and $T$. begoniifolia due to transport fumes only, but decreased in the seeds of all linden species, as well as in the dormant buds (except T. begoniifolia). In general, it should be recognized that a substantial restructuring of the components of the antioxidant system in the buds, leaves and seeds was required for adaptation of each Tilia species to the chronic influence of pollutants. The results obtained suggest that the pollutant-induced decrease in the activity of antioxidant enzymes in the organs of Tilia species can be connected with in the deterioration of physiological features, such as a reduction of pollen fertility (Jusypiva and Korostylova, 2015) and seed production (Yerofeyeva, 2014). On the other hand, significant activation of enzymes in the seeds and buds could indicate an increase in the antioxidant adaptive capacity of the next generation of linden trees exposed to chronic contamination, which is similar to the assumption made earlier in studying the pollutant-induced activation of glutathione-dependent system of Acer dormant buds (Khromykh, 2014). The results of both studies results are consistent with the hypothesis of Walter et al. (2013) that severe conditions are able to induce the formation of ecological stress memory in plants, increasing resistance to adverse environments.

\section{Conclusion}

In the present paper the influence of transport fumes and industrial waste on catalase, benzidine-peroxidase, and guaiacolperoxidase activity in leaves, buds and seeds of various species of Tilia genus was studied. In the dormant buds, a high reference level of catalase activity changed slightly for any type of contamination, and notable enzyme activation was revealed in the buds of T. europaea and T. begoniifolia. On the contrary, activities of benzidine-peroxidase and guaiacolperoxidase declined abruptly in the buds of all linden species, except $T$. begoniifolia where both enzyme activities increased essentially. In leaves, a relatively low reference level of catalase activity was exceeded by $2-3$ times due to the action of pollutants for all species, especially for $T$. amurensis. Regarding peroxidase activity of leaves, this was the lowest among the examined linden organs. There was a notably sharp inhibition of benzidine-peroxidase activity in all species influenced by industrial emissions except $T$. begoniifolia, as well as a reduction in guaiacol-peroxidase activity in leaves of T. platyphyllos and T. europaea, but significant enzyme activation in T. amurensis and T. begoniifolia leaves.

In the seeds, the high reference level of catalase activity increased by 1.8 times for T. platyphyllos and T. europaea, and grew slightly for $T$. amurensis, while it was reduced abruptly in the seeds of $T$. begoniifolia due to the action both of transport and industrial emissions. A relatively high benzidine-peroxidase reference activity level was significantly reduced in the seeds of all Tilia species from contaminated plots. At the same time, guaiacol-peroxidase activity reduction was observed only in the seeds of T. europaea and T. begoniifolia, while an increase ( 2 and 2.8 -fold) in the enzyme activity occurred in the seeds of T. platyphyllos and T. amurensis.

The study results have confirmed the hypothesis that a significant restructuring of the antioxidant system takes place in the dormant buds, leaves and seeds of Tilia trees during their developmental stages due to the effect of pollutants in contaminated urban phytocenoses. 


\section{References}

Allison, S.D., Schultz, J.C., 2004. Differental activity of peroxidase isozymes in response to wounding, gypsy moth, and plant hormones in Nothern red oak (Quercus rubra L.), J. Chem. Ecol. 30(7), 1363-1379.

Anicic, M., Spasic, T., Tomasevic, M., Rajsic, S., Tasic, M., 2011. Trace elements accumulation and temporal trends in leaves of urban deciduous trees (Aesculus hippocastanum and Tilia sp.). Ecol. Indic. 11(3), 824-830.

Chirkova, T.V. (ed.), 2002. Phiziologicheskye osnovy ustoychivosty rasteniy [Physiological basis of plant resistance]. St. Petersburg Univ. Press, St. Petersburg (in Russian).

Deniz, M., Duzenli, S., 2007. The effect of refinery pollution on non-enzymatic foliar defense mechanisms in four evergreen plants species in Turkey. Acta Physiol. Plant. 29, 71-79.

Divan, A.M., Oliveira, P.L., Perry, C.T., Atz, V.L., AzzariniRostirola, L.N., Raya-Rodriguez, M.T., 2009. Using wild plant species as indicators for the accumulation of emissions from a thermal power plant, Candiota, South Brazil. Ecol. Indic. 9, 1156-1162.

Dragistic-Maksimović, J., Maksimović, V., Živanović, B., Hadži-Tašković, Š.V., Vuletić, M., 2008. Peroxidase activity and phenolic compounds content in maize root and leaf apoplast and their association with growth. Plant Sci. $175(5), 656-662$.

Fisher, S., Nicholas, N.S., Scheuerman, P.R., 2002. Dendrochemical analysis of lead and calcium in Southern Appalachian American Beech. J. Environ. Qual. 31, 1137-1145.

Gill, S.S., Tuteja, N., 2010. Reactive oxygen species and antioxidant machinery abiotic stress tolerance in crop plants. Plant Phys. Biochem. 48(12), 909-930.

Goth, L., 1991. A simple method for determination of serum catalase activity and revision of reference range. Clin. Chim. Acta 196, 143-152.

Gregory, R.P.F., 1966. A rapid assay for peroxidase activity. Biochem. J. 101(3), 582-583.

Halliwell, B., 2006. Reactive species and antioxidants. Redox biology is a fundamental theme in aerobic life. Plant Phys. 141, 312-322.

Hammond-Kosack, K.E., Jones, J.D.G., 1996. Resistance gene-dependent plant defense responses. Plant Cell 8(10), 1773-1791.

Jusypiva, T.I., Korostylova, T.S., 2015. Vplyv tekhnohennoho navantazhennia na fiziolohichni ta tsytohenetychni pokaznyky heneratyvnykh orhaniv predstavnykiv rodu Tilia [Technogenic impact on physiological and cytogenic indices of reproductive organs of Tilia genus representatives]. Vìsn. Dnìpropetr. Unìv. Ser. Bìol. Ekol. 23(1), 10-14 (in Ukrainian).

Kardel, F., Wuyts, K., Babanezhad, M., Wuytack, T., Adriaenssens, S., Samson, R., 2012. Tree leaf wettability as passive bio-indicator of urban habitat quality. Env. Exp. Bot. 75(1), 277-285.

Khromykh, N., 2014. Reaction of glutathione-dependent system of Acer trees vegetative buds to pollutants' action. Visnyk of the Lviìv Unìversity. Serìes Bìology 67, 268-273.

Khromykh, N.O., Bilchuk, V.S., Rossykhina-Galycha, G.S., Vinnychenko, O.M., 2014. Sezonna dynamika antyoxidantnykh protsessiv u lystkah Acer negundo za diy polyutantiv [Seasonal dynamics of antioxidative processes in Acer negundo leaves under pollutant action]. Vìsn. Dnìpropetr. Unìv. Ser. Bìol. Ekol. 22(1), 71-76 (in Ukrainian).
Kosiba, P., 2008. Variability of morphometric leaf traits in small-leaved linden (Tilia cordata Mill.) under the influence of air pollution. Acta Soc. Bot. Pol. 77(2), 125-137.

Madejon, P., Maranon, T., Murillo, J.M., Robinson, B., 2004. White poplar (Populus alba) as a biomonitor of trace elements in contaminated riparian forests. Environ. Pollut. 132, 145-155.

Matyssek, R., Wieser, G., Calfapietra, C., Vries, W., Dizengremel, P., Ernst, D., Jolivet, Y., Mikkelsen, T.N., Mohren, G.M.J., Thies, D., Tuovinen, J.-P., Weatherall, A., Paoletti, E., 2012. Forest under climate change and air pollution: Gaps in understanding and future direction for research. Environ. Pollut. 160, 57-65.

Pakhomov, O.Y., Brygadyrenko, V.V., 2005. Koncepcija systemy zahodiv z ohorony navkolyshn'ogo pryrodnogo seredovyshha Dnipropetrovs'koi' oblasti na 2005-2015 roky [Concept of system for actions on environment protection in Dnipropetrovsk region for 2005-2015]. Vìsn. Dnìpropetr. Unìv. Ser. Bìol. Ekol. 13(1), 213-225.

Polovnikova, M.G., Voskresenskaya, O.L., 2008. Aktivnost komponentov antioksidantnoy zaschity i polifenoloksidazy u gazonnykh rasteniy $\mathrm{v}$ ontogeneze $\mathrm{v}$ usloviyakh gorodskoy sredy [Activity of antioxidative Defense components and polyphenoloxidase of lawn plants during ontogenesis under urban conditions]. Russ. J. Plant Physl. 55(5), $777-785$ (in Russian).

Ramel, F., Sulmon, C., Serra, A.-A., Gouesbet, G., Couee, I., 2012. Xenobiotic sensing and signaling in higher plants. J. Exp. Bot. 63(11), 3999-4014.

Ranieri, A., Castagna, A., Baldam, B., Soldatini, G.F., 2001. Iron deficiency differently affects peroxidase isoforms in sunflower. J. Exp. Bot. 52, 25-35.

Ranieri, A., Castagna, A., Lorenzini, G., Soldatini, G.F., 1997. Changes in thylakoid protein patterns and antioxidant levels in two wheat cultivars with different sensitivity to sulphur dioxide. Environ. Exp. Bot. 37, 125-135.

Roy, S., Byrne, J., Pickering, C., 2012. Asystematic quantitative review of urban tree benefits, costs, and assessmentmet hods across cities in different climatic zones. Urban For. Urban Gree. 11, 351-363.

Sheykholeslami, A., Namiranian, M., Sagheb-Talebi, K., 2011. A study of large-leaved lime (Tilia platyphyllos Scop.) in forests of Western Mazandaran. J. Biodivers Ecol. Sci. 1(1), 65-75.

Striletz, R.O. (ed.), 2015. Ekologichnij pasport Dnipropetrovskoi oblasti [Ecological passport of Dnipropetrovsk region]. Dnipropetrovsk (in Ukrainian).

Tomasevic, M., Rajsic, S., Dordevic, D., Tasic, M., Krstic, J., Novakovic, V., 2004. Heavy metals accumulation in tree leaves from urban areas. Environmental Chemistry Letters 2, 151-154.

Tsvetkova, N.M., Pakhomov, O.Y., Serdyuk, S.M., Yakyba, M.S., 2016. Biologichne riznomanittja Ukrajiny. Dnipropetrovs'ka oblast'. Grunty. Metaly u gruntah [Biological diversity of Ukraine. The Dnipropetrovsk region. Soils. Metalls in the soils]. Lira, Dnipropetrovsk (in Ukrainian).

Walter, J., Jentsch, A., Beierkuhnlein, K., Kreyling, J., 2013. Ecological stress memory and cross stress tolerance in plants in the face of climate extremes. Env. Exp. Bot. 94(10), 3-8.

Yerofeyeva, E.A., 2014. Dependence of drooping birch (Betula pendula) and lime tree (Tilia cordata) relative seed production as a new seed production index on the intensity of motor traffic pollution. Adv. Environ. Biol. 8, 282-286.

Надійшла до редколегї 16.03.2016 